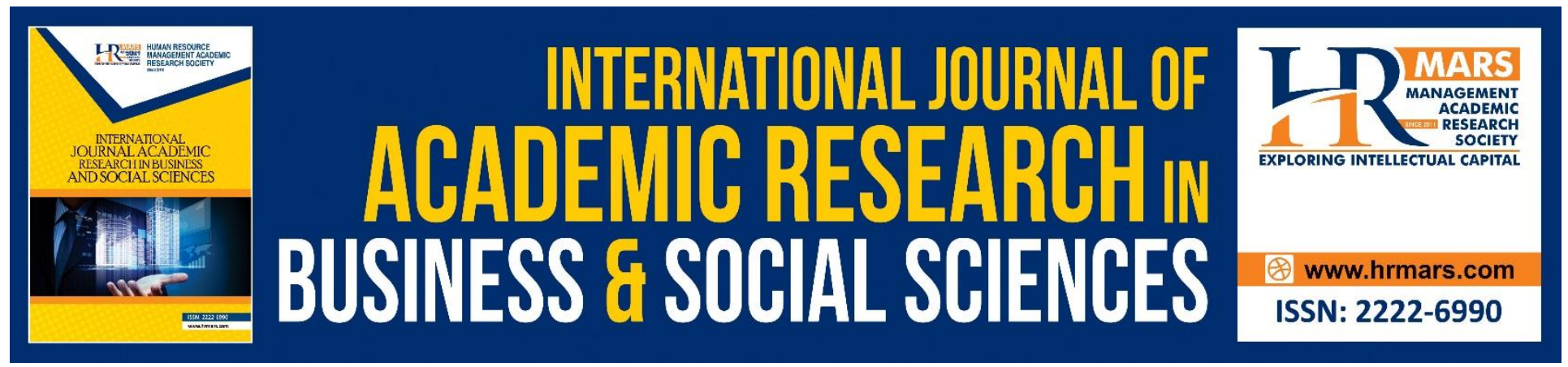

\title{
Micro Small and Medium Enterprise Demand for General Takaful: Proposed Theoretical Framework and Hypotheses Development
}

Fauzilah Salleh, Mohamed Dahlan Ibrahim, Ahmad Shukri Yazid, Zainudin Awang, Asyraf Afthanorhan, Norfadzilah Rashid, Puspa Liza Ghazali

To Link this Article: http://dx.doi.org/10.6007/IJARBSS/v8-i12/5058

DOI: $10.6007 /$ IJARBSS/v8-i12/5058

Received: 07 Nov 2018, Revised: 17 Dec 2018, Accepted: 25 Dec 2018

Published Online: 29 Dec 2018

In-Text Citation: (Salleh et al., 2018)

To Cite this Article: Salleh, F., Ibrahim, M. D., Yazid, A. S., Awang, Z., Afthanorhan, A., Rashid, N., \& Ghazali, P. L. (2018). Micro Small and Medium Enterprise Demand for General Takaful: Proposed Theoretical Framework and Hypotheses Development. International Journal of Academic Research in Business and Social Sciences, 8(12), 599-612.

Copyright: (C) 2018 The Author(s)

Published by Human Resource Management Academic Research Society (www.hrmars.com)

This article is published under the Creative Commons Attribution (CC BY 4.0) license. Anyone may reproduce, distribute, translate and create derivative works of this article (for both commercial and non-commercial purposes), subject to full attribution to the original publication and authors. The full terms of this license may be seen

at: http://creativecommons.org/licences/by/4.0/legalcode

Vol. 8, No. 12, 2018, Pg. 599 - 612

http://hrmars.com/index.php/pages/detail/IJARBSS

JOURNAL HOMEPAGE

Full Terms \& Conditions of access and use can be found at http://hrmars.com/index.php/pages/detail/publication-ethics 


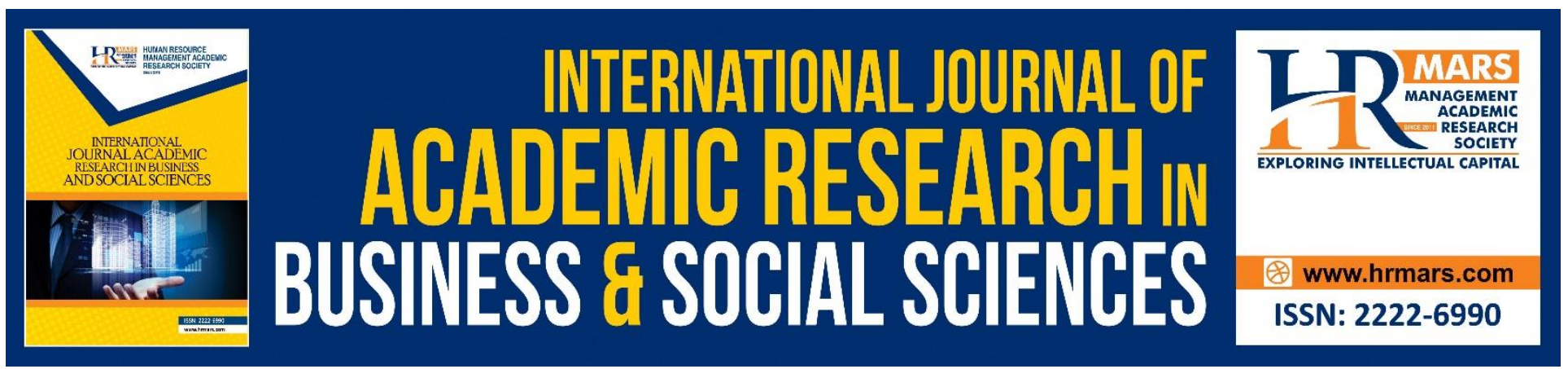

\title{
Micro Small and Medium Enterprise Demand for General Takaful: Proposed Theoretical Framework and Hypotheses Development
}

\author{
Fauzilah Salleha, Mohamed Dahlan Ibrahim ${ }^{\mathrm{b}}$, Ahmad Shukri Yazida, \\ Zainudin Awanga , Asyraf Afthanorhan, Norfadzilah Rashid, Puspa \\ Liza Ghazalia \\ ${ }^{a}$ Department of Finance, Faculty of Economics and Management Sciences, \\ Universiti Sultan Zainal Abidin (UniSZA), Terengganu, Malaysia \\ ${ }^{b}$ Department of Finance, Faculty of Entrepreneurship and Business, \\ Universiti Malaysia Kelantan (UMK), Kelantan, Malaysia. \\ Corresponding author: drasyrafafthanorhan@gmail.com
}

\begin{abstract}
To guarantee an enterprise's survival and its development, the demand for insurance exists. This will possibly result to an individual resorting to risky actions for the sake of his/her organization. In fact, the rate of insurance penetration is still low although entrepreneurs' businesses are growing rapidly. This paper aims to identify specific elements in an organization which give impacts on the general demand for Takaful product. Furthermore, readings of literature are studied in detail to create organization's characteristics for insurance demand. This literature reading is also done in order to describe the existing models of general Takaful demand. As a result, it is found that the characteristics of organization for general insurance demand comprise of geographical concentration, line of business, size, and regulation. In this study, the predicted utility theory of the organization's owner is assimilated for the creation of a suitable model and framework for the research regarding the demand for general Takaful. In previous studies, the aspect of the impact of the risk-taking propensity, depending on the level of risk, as a key mediating variable were not focused on. Additionally, this paper also aims to provide future suggestions circulating around this matter. This matter holds a relatively high significance where thorough examination and documentation is conducted. Another reason for its significance is the scarce amount of research on this area in Malaysia. Besides, the number of empirical research performed on Takaful is still scarce although the investigation into Takaful demand, specifically regarding the methods of enhancing market penetration, has been conducted for almost 30 years in Malaysia.
\end{abstract}

Keywords: Organization's Characteristics, Risk-Taking Propensity, General Takaful Demand, 


\section{Introduction}

There has been a continuous growth in the Takaful industry in Malaysia since its formation during the past two decades. The factor of this is its organized development, which is coupled with the support provided by a pragmatic and holistic strategy. As a result, a remarkable progress can be seen in the growth of the Islamic financial industry. Furthermore, there has been a remarkable development in Takaful operator, which can be seen from the significant increase in the number of Takaful operators since 1984. To be specific, it started with just one Takaful operator. Subsequently, this number has developed into nine Takaful operators, 4 re-Takaful operator, and an International Takaful operator. They have a role in the diversification of the marketing strategies of Takaful products to fulfill the economy's financial needs while abiding by Shariah requirements. Currently, the methods of marketing Takaful products continue to grow in order to cater to customer's different needs. Moreover, family Takaful products have ruled the market, with its share of net contribution amounting to 78 percent. This amount surpasses the general Takaful products which have ruled the stock with 63 percent share of net contribution since 1984. The high potential of Takaful industry can be seen from the high rate of its overall assets yearly and the percentage of its contributions which ranged from 20 to 26 percent around 2004 to 2009. Despite the low rate of its current development, the Takaful sector's strength is maintained in the aspect of its growth prospects. This is due to its potential which is yet to be unleashed. This refers to Takaful and insurance's market penetration rate, which amounted to 53.5 percent, while the rate of Takaful's market penetration only amounted from $10 \%$ to 5.05 million in 2016.

The growth of Takaful Business in Malaysia abides by the insurance law, which was reinforced by the Fatwa Council in Sudan in 1979. This was followed by the commencement of Islamic insurance or Takaful Act's establishment by Malaysia's government in November 1984. Fatwa Council is an organization which was participated by scholars worldwide in 1979. The purpose of this participation was for discussion and review regarding the Takaful system, specifically on whether it abides by the requirement outlines by Shariah and the Prophet. Subsequently, the organization has met a decision to PROHIBIT today's conventional insurance due to the presence of gambling, uncertainty, and interest.

General demand for insurance, which is for organization's survival and development, will possibly result in the managers resorting to risky actions for the sake of the organization (Greenwald and Stinglitz, 1993; 1990). In supporting this inference, Mayers and Smith (1982) and Han (1996) highlight in their research that, due to the incentive which Pure Risk associated to business offers for company's reputations and interests protection and purchase of property insurance, organization owners tend to undertake risky actions. There has been a continuous development of Micro Small and Medium Enterprises (MSMEs). However, the penetration rate of risk or insurance management is still low even though there is a wide range of option to choose for business protection within local boundaries. To prove this point, it can be seen from the disadvantage faced by a number of MSMEs in Malaysia when global financial crisis occurred in 2008 and 2009 as an impact of low demand for general Takaful protection. Therefore, provided the scarce amount of research in this area in Malaysia, knowledge of the influencing socioeconomic factors of the general demand for Takaful is essential. During the decision-making process of owner/managers of MSMEs upon their insurance purchase, the level of tendency towards risky action is an important factor which aids them in making 
the best decision for their organization's survival. However, the tendency towards risk-taking among MSMEs comprises of wide range of levels, although they are generally low. In addition, although numerous MSMEs owners/managers' tendency towards risk-taking and attitudes toward insurance are at particular levels, most of them fail in explaining the association between these and the demand for insurance. Due to insufficient empirical evidence of risk-taking propensity, there has been a disparity between the practice and theory of the level of tendency towards risky actions when the demand for Takaful is concerned. In this study, the level of tendency towards risky actions and the theories of the general demand for insurance among organization were assimilated for the development of a framework and model appropriate for this research where the demand for Takaful was the subject of focus. In particular, risk-taking propensity plays the role as a mediator of the association between organization's characteristics and general Takaful demand. However, its impact was a topic which was not focused on in previous research. Additionally, the number of empirical research on Takaful is still scarce despite Takaful has been operating for almost 30 years in Malaysia.

Due to the significance of insurance coverage as a tool for an organization to grow and remain strong, models of general Takaful demand's framework with distinguished attributes, which were suitable for investigation on the characteristics of organization for the demand among MSMEs, were designed in this research. Furthermore, this study attempted to determine the organization's characteristics for MSMEs' demand for Takaful in Malaysia. The variables which were emphasized in this research consisted of the features of organization and the level of risk-taking propensity. Each of MSMEs involved in this study needed to take these variabled into account before registering for any Takaful plan.

The development of the insurance framework took place in 1990 (Mayers and Smith, 1982). With this, it is possible to determine four attributes of an organization which the process of identifying organization's characteristics, which is done by viewing literature, is based on. This process is where organization's characteristics, such as geographical concentration, line of business, regulation, and size, are acquired and applied (Figure 1).

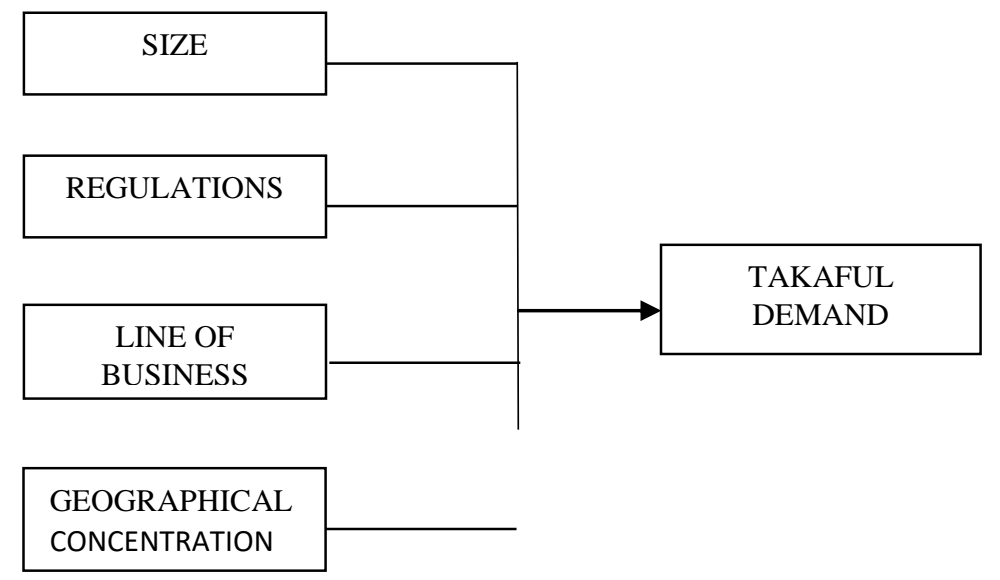

Figure 1: Dimensions of the Model for the Demand for Insurance 
The scope of this study holds an importance in the development of the new model for general Takaful demand. With comprehension of the influencing factors of the coverage of Islamic products among general users, the quality of protection provided by the demand for general Takaful can be improved through blessings and long-term success. Furthermore, the association between the organization characteristics and the risk-taking propensity among entrepreneurs of small and micro business is a crucial information. This is due to the increasing number of people who are interested in entrepreneurship as the government intends to provide more facilities to the entrepreneurs, such as training, loan, grants, and other incentives in order to promote entrepreneurship. Moreover, the findings of this study would provide further understanding of the profile regarding the risk-taking propensity among entrepreneurs of small and micro business, specifically in the aspect of organization's features. Besides, investigation of the mediating impacts of the risk-taking propensity on the association between organization's features and general Takaful products demand level is another significant contribution of this research. Therefore, this study's context is important due to the insufficient amount of investigation performed on the risk-taking propensity among business owners in Malaysia in comparison to developed countries. As for developed countries, products which are compliant to Islamic values are prioritized, making the products suitable and practical for everyone, particularly Muslims.

\section{Literature Review}

\section{Dependent Variable}

Based on the literatures studied for this research, it is found that, as shown in Table 1, all research dated from 1990 to 2017 involved the use of insurance premium as a proxy of general insurance demand. The number of Takaful policy will be used in this research, as the involvement of Takaful organizations in this research is due to the demand for it. It can also be said that the Takaful Contribution is the dependent variable of this research, which utilizes the number of Takaful guidelines for the guidelines in every organization. Another reason for the difficulty to obtain the records of financial statements is that the sample of respondents comprises of MSMEs. Moreover, this research will be carried out through questionnaire. On the other hand, insurance premium was used in previous research to measure insurance demand due to the availability of secondary data on the financial statement from each organization. In fact, insurance premium is an instrument for measurement of both compounds, which are specifically unit price and quantity. Additionally, as the sample of financial statements is created by large organizations, as well as publicly listed organizations, they are easily obtainable. There is a wide range of unit price based on the level of risk for those who are insured.

In the research by Mayers and Smith Jr (1990) and Cole and McCullough (2006), reinsurance premiums was used as a demand for proxy of insurance through calculation of the ratio of purchase reinsurance to insurance premiums. On the other hand, in the studies by other researchers, namelyYamori (1999); Hoyt and Ho (2000); Zou, Adams, and Buckle (2003), Daniel and Paul (2003); Zou and Adams (2005); Zou and Adams (2006); Hamid (2010); Fang, Kui, and Zhu (2011); Burhan et al., (2017); Mike, Chen and Hong (2011); Kerjan, Raschky \& Kunreuther (2011); Adams et al. (2011) and Ehling, Kalay \& Pant (2012), the property insurance premiums were used as a demand for proxy insurance. However, as for the study regarding Malaysian Takaful demand which were performed by 
Hamid, Osman, and Nordin (2009); Ibrahim, Salleh and Awang (2015) and Salleh, Ibrahim, Awang, Yazid, Wan Daud, Abdul Razak, Yaakub, Ghazali, Mohamad, \& Hashim (2017), contribution of the general Takaful was used as the demand for a Takaful proxy. With general demands for Takaful in Malaysia as the focus of research, contribution of the general Takaful will be investigated. However, the aspects of the amount of guidelines and the samples for MSMEs will be examined through survey. This research applied a method different from the method applied in the study by Hamid et al. (2009), where publicly listed organizations were made their research sample, as well as secondary data. These studies became the perfect addition to the study regarding the demand for Takaful in Malaysia due to the involvement of business owners from organizations ranging from micro to big/giant organizations. Besides, the method in this research is also in similar to the method in the studies by Hoyt and Khang (2000), Burhan. Salleh, \& Burhan (2015), and Lin, Lin, Zou (2012), where survey was conducted on organizations in order to evaluate the general demand for insurance in the case of their study sample. The evaluation was performed through a variable to assess the demand for Takaful, which was corresponding to the amount of Takaful guidelines for each MSME.

\section{Independent Variables}

A large amount of literature have discussed on the demand for insurance protection among individuals. The application is conducted based on expected utility theory by Martin Fishbein (1980), the contingent claims theory created by Debreu (1953), the state-preference method developed by Arrow (1953), and theory of expected utility (EU) by Von Neumann and Morgenstern (1944). Other theories implemented in the literatures are Capital Assets Pricing Model (CAPM) by William Sharpe (1964) and John Lintner (1965) for estimation of the expense of capital for organizations and assessment of the managed portfolios performance. Even so, the components of expected CAPM and EU will be the focus of this research so that a benchmark model for general demand for insurance with empirical results can be created. 
INTERNATIONAL JOURNAL OF ACADEMIC RESEARCH IN BUSINESS AND SOCIAL SCIENCES Vol. 8, No. 12, Dec, 2018, E-ISSN: 2222-6990 @ 2018 HRMARS

Table 1: Several Empirical Researches on The Dependent Variables of General Demand For Insurance

\begin{tabular}{|c|c|c|}
\hline Author (Year) & Dependent Variable(s) & Data \\
\hline Mayers and Smith (1990) & Reinsurance Premium & Secondary Data \\
\hline E.Core (1997) & Director \& Officers Insurance & Secondary Data \\
\hline Yamori (1999) & Insurance Premium & Secondary Data \\
\hline Hoyt and Khang (2000) & Property Insurance Premium & Secondary Data \& survey \\
\hline $\begin{array}{l}\text { Zou, Adams and Buckle } \\
\text { (2003) }\end{array}$ & Property Insurance Premium & Secondary Data \\
\hline Daniel and Paul (2003) & Property Insurance Premium & Secondary Data \\
\hline Zou and Adams (2005) & Property Insurance Premium & Secondary Data \\
\hline Cole and McCullough (2006) & Reinsurance Premium & Secondary Data \\
\hline Zou and Adams (2006) & Property Insurance Premium & Secondary Data \\
\hline Regan and Hur (2007) & Insurance Premium & Secondary Data \\
\hline $\begin{array}{l}\text { Hamid, Osman, Ariffin and } \\
\text { Nordin (2009) }\end{array}$ & General Takaful Contribution & Secondary Data \\
\hline Hamid (2010) & Property Insurance Premium & Secondary Data \\
\hline Chen and Li (2010) & D\&O Insurance Premium & Secondary Data \& Survey \\
\hline Zhu, Kui, and Fang (2011) & Property Insurance Premium & Secondary Data \\
\hline Mike, Chen and Hong (2011) & Property Insurance Premium & Secondary Data \\
\hline $\begin{array}{l}\text { Kerjan, Raschky and } \\
\text { Kunreuther (2011) }\end{array}$ & $\begin{array}{l}\text { Property and Catastrophe } \\
\text { Insurance }\end{array}$ & Secondary Data \\
\hline Adams, Lin and Zou (2011) & Property Insurance Premium & Secondary Data \\
\hline Lin, Lin \& Zou (2012) & $\begin{array}{l}\text { 1. Purchase of insurance } \\
\text { 2. Ratio of total expenses for } \\
\text { insurance }\end{array}$ & Secondary Data \\
\hline Ehling, Kalay and Pant (2012) & Property Insurance Premium & Secondary Data \\
\hline $\begin{array}{l}\text { Ibrahim, Salleh and Awang, } \\
\text { (2015) }\end{array}$ & General Takaful Contribution & Secondary Data \& Survey \\
\hline $\begin{array}{l}\text { Salleh, Ibrahim, Awang, Yazid, } \\
\text { Wan Daud, Abdul Razak, } \\
\text { Yaakub, Ghazali, Mohamad, } \\
\text { and Hashim (2017) }\end{array}$ & General Takaful Contribution & Primary \& Secondary Data \\
\hline
\end{tabular}

As shown in Table 2, number of research have provided explanation on the demand for insurance based on the perspective of organization's features. Through these studies, further comprehension and elaboration on the impacts of organization's features on an individual's decisionmaking process upon insurance purchase are provided. Subsequently, there is no consistency in the empirical results across studies. Besides, there are numerous cases where the impacts of organization's features with demand for insurance ranges from positive, negative, to insignificant. 
According to Lin, Lin \& Zou (2012); Adams, Lin \& Zou (2011); Hamid (2010); Hamid, Osman, Ariffin, Nordin (2009); Zou and Adam (2006); Zou, Adams and Buckle (2003); Hoyt and Khang (2000); Yamori (1999); and Mayers and Smith (1990), positive association between organization's size and insurance purchase is inherently expected. However, Regan and Hur (2007) and Cole \& McCullough (2006) finds that organization's size has a negative association with insurance purchase.

Although there is supposed to be a clear association between organization's regulation and the demand for insurance, uncertainty is still present. This can be seen from the fact that although Hoyt and Khang (2000) finds this association to be negative, Regan and Hur (2007); MacMinn and Garven (2000); and Yamori (1999) have an opposite finding on this matter. Nevertheless, no significant relationship between these two variables is found by Hamid, Osman, Ariffin, Nordin (2009) and Hamid (2010). Based on a research by Yamori (1999), similar to organization's regulation and size, organization's line of business provides a positive outcome on general demand for insurance. Therefore, given the inconsistent results of previous studies, continuation of this investigation is relevant. However, neither of them abided by the regulations provided by model during their decision-making process upon insurance purchase (Mason et al., 2005; Neilson 2002), especially Takaful protection demand.

Table 2: Some Empirical Studies of the Independent Factors of General Demand or Insurance

\begin{tabular}{|c|c|c|}
\hline Variables & Positive & Negative \\
\hline Size & $\begin{array}{l}\text { Mayers \& Smith (1990) } \\
\text { Zou \& Adam (2006) } \\
\text { Zou, Adams \& Buckle (2003) } \\
\text { (Decision M) } \\
\text { Hamid, Osman, Ariffin \& } \\
\text { Nordin (2009) } \\
\text { Hamid (2010) } \\
\text { Adams, Lin \& Zou (2011) } \\
\text { Lin, Lin \& Zou (2012) }\end{array}$ & $\begin{array}{l}\text { Yamori (1999) } \\
\text { Hoyt \& Khang (2000) } \\
\text { Zou, Adams \& Buckle (2003) } \\
\text { (Volume) } \\
\text { Regan \& Hur (2007) } \\
\text { Cole \& McCullough (2006) }\end{array}$ \\
\hline Regulation & $\begin{array}{l}\text { Yamoi (1999) } \\
\text { MacMinn \& Garven (2000) } \\
\text { Regan \& Hur (2007) }\end{array}$ & Hoyt \& Khang (2000) \\
\hline Line of Business & Mayers \& Smith (1990) & Cole \& McCullough (2006) \\
\hline Geographical Concentration & $\begin{array}{l}\text { Mayers \& Smith (1990) } \\
\text { Cole \& McCullough (2006) } \\
\text { Zou, Adams \& Buckle (2003) }\end{array}$ & \\
\hline
\end{tabular}

In the case of the risk-taking propensity among business owners, research into this matter was conducted by Carland, Carland and Carland (1995) on 848 respondents, who comprised of 387 managers, 347 small business owners, and 114 entrepreneurs. From the study, risk-taking propensity 
in entrepreneurship was found to be higher among business owners in comparison to the managers. Overall, the particular group with the highest risk-taking propensity was entrepreneurs, followed by small business owners and managers. Furthermore, the differences between American and Finnish managers, entrepreneurs, and small business owners, specifically in the aspect of the level of risktaking propensity, were investigated by Koiranen, Hyrsky and Tunnanen (1997). As a result, it was found that, American entrepreneurs, small business owners and managers had higher risk-taking propensity compared to their Finnish counterparts. Besides, it is highlighted by Balabanis and Katiskea (2003) that organization's size provides direct impact on risk-taking propensity. To illustrate this, larger pool of resources are available in bigger organizations. This provides more capacity for risk-taking and variation of products and markets. For this reason, losses in marketing due to failed entrepreneurial efforts are not allowed in this type of organizations. Additionally, the expectation for higher level of risk-taking propensity is higher in bigger companies in comparison to smaller companies. Leko-Simic and Horvat (2006) performed an analysis on organizations in terms of type of business, size, and duration of operation as the influencing factors of risk-taking propensity. This investigation was conducted on 300 Croatian exporters, who represented $10 \%$ of active exporters randomly assigned from the Croatian Chamber of Commerce database. They were separated into two segments, namely 'risk-taking and 'non-risk-taking'. Statistical inferential analysis was conducted, with consideration on various aspects, such as the subjective and objective risk-taking propensities of the samples' export performance. As a result, a vast difference between 'risk-taking' and 'non-risk-taking' segments were found, although their risk-taking propensity was not significant when international business was conducted. Therefore, hypotheses of the relationships are formulated as follows:

Hypothesis 1a: Organization's size poses a direct and positive influence on risk-taking propensity. Hypothesis 1b: Organization' size poses a direct and positive influence on general Takaful demand. Hypothesis 2a: Regulated organization poses a direct and positive influence on risk-taking propensity.

Hypothesis 2b: Regulated organization poses a direct and positive influence on general Takaful demand.

Hypothesis 3a: Organization's line of business poses a direct and positive influence risk-taking propensity.

Hypothesis 3b: Organization's line of business poses a direct and positive influence on general Takaful demand.

Hypothesis 4a: Organization's geographical concentration poses a direct and positive influence on risktaking propensity.

Hypothesis 4b: Organization's geographical concentration poses a direct and positive influence on general

Takaful demand. 


\section{The Mediating Impacts of the Risk-taking Propensity on the Demand for General Takaful}

The aversion of risk and the demand for insurance come together. Furthermore, these two factors are commonly involved in insurance with different individual's and general's point of views. It is presumed by Von Neumann and Morgenstern (1944), who are the founders of expected utility theory, that risk aversion is the basic principle of the behaviours displayed by individuals upon insurance purchase. This theory is the basis of the explanation of the tendency of risk-averse individuals towards insurance purchase rather than registering for self-insurance. Risk aversion defines an individual's preference for a less risky alternative. However, when both options provide long-term financial rewards, a more significant uncertainty is not present in this option (Cather, 2010). Furthermore, this is used to describe the decision-making process of an individual during situations where their financial state is at stake. Such situations range from investment to gambling. For risk-averse individuals, the acquirement of insurance coverage is either for the purpose of protection of themselves or their property. Additionally, benefits can be obtained during the occurrence of sustained accidental losses. It can also be said that during the reduction of future uncertainty, reduction of wealth will occur, along with the increase of individual's expected utility. These are the outcomes which take place upon the continuous concave and increase of the functions of individual's risk aversion utility. With this, through comparison of utilities related to various impacts of individual's finance, they will decide for a purchase of a small premium for protection from significant financial losses. Therefore, with the protection of insurance coverage, the buyer will be rest assured on their property.

The impacts of risk-taking propensity on general demand for insurance is the issue which is not focused by most of the present research and literature. In economic literatures, not only risk-aversion has been highlighted, it also poses a significant influence on the demand for insurance. However, provided that risk-taking propensity and entrepreneurship are related to each other, the impacts of risk-taking propensity on general Takaful demand should not be taken lightly. Fortune (1973) implemented the expected utility hypothesis of choice under uncertainty in order to determine the favourable amount of life insurance for an individual. From that, it can be seen that an individual's risk-taking propensity will be reduced with the increase of absolute risk aversion. Besides, an individual will be more willing to pay more for insurance premium for risk reduction. In the theoretical framework regarding adverse selection by Eisenhauer (2004), the influence of risk and risk aversion on the demand for insurance was analyzed. From that, it was inferred that the risk aversion of lowrisk applicant is higher than the risk aversion of their high-risk counterparts. With this, the willingness of the former applicant will be equal or higher than the willingness of the latter when it comes to purchasing insurance at any price charged on it.

There is a contradiction between risk aversion and risk-taking propensity with the fact that insurance will not be demanded by an individual or business with high risk-taking propensity, especially on whether this fact is true or vice-versa. It is possible for people under the business sector to avoid several risks. However, without several risks being sustained, it is impossible to conduct business activities. To illustrate, when bankruptcy occurs due to unpleasant incidents happening in a business premise fire, will the business will be impacted in overall, especially when it closes down. With this, the question on whether it is possible for business owners to not start business due to fear of bankruptcy emerges. Therefore, risk-taking propensity among entrepreneurs for 
continuous business operation is important. Besides, they will demand for general insurance protection from the risk fire occurring to the premises. From here, it is indicated that, despite the inconsistency of risk-taking propensity and risk aversion in terms of insurance demand, both altogether could contribute to a successful business, especially among MSMEs.

Although investigation into the influence of risk aversion on individual's behaviour upon insurance purchase from the perspective theory was conducted by researchers such as Szipiro (1985) and Hoy and Robson (1981), there is an insufficient amount of empirical research. Besides, there was contradiction between each research, as the research by Schlesinger (1981) found a correlation between the degree of risk aversion among consumers and the amount of the purchased insurance policy. To illustrate this, high degree of aversion was displayed by more purchased insurance policies. In contrary to the results of the research by Burnett and Palmer (1984), it was shown from a research on life insurance method that many of life insurance policies were purchased by consumers, where most of them were higher risk takers. Moreover, the research conducted by Schlesinger (1981) was different from the ones by Burnet and Palamer (1984). This was due to the different area of focus for both research, even in the aspect of risk-taking propensity and risk aversion. According to a research on group insurance by Jacobson and Petrie (2009), the differences in terms of risk-taking propensity between the research by Schlesinger (1981) and the research by Burnet and Palamer (1984) were found. To be specific, the association between risk aversion and the demand for insurance being a member of the group was not found. This was due to the difficulty in evaluating the influence and risky behaviours in empirical studies. To illustrate this, it was possible for the levels of risk-taking to be varied when a situation related to finance, such as health and relationships with people, occurred. Individual's behaviours, whether to pose risk acceptance or avoidance, depend on various situations. To be specific, there are situations where they need to be accepting towards risk, and vice versa. This was due to the difficulty for even psychologists or economics to create psychological questionnaire for prediction of individual's risk-taking behavior across multiple domains (Nicholson et al. 2002).

Due to the incapability of predicting risk-taking behavior across multiple domains, this topic has been highlighted from a biological perspective. To illustrate this, the research by Ottaviani and Vandone (2011), psychological factors were used to measure risk propensity, where psychological factors were used in order to identify insurance demands. It was found from this research that behaviors of individuals who decide on insurance purchase posed an influence on their decisionmaking process regarding the demand for insurance. In this study, the lowa Gambling Task was used along with skin conductance recording. This is a task which is qualified through a trial decision made under ambiguity which displays two performances by risk-taking. These two performances were conducted as a method of evaluating risk propensity, while somatic markers played a role in evaluating risk perception, which was referred to an individual's capability of being independent from high-risk attitudes and "feeling" the risk. The sample of this research consisted of 445 households, and socio-economic demographic profiles were acquired. Besides confirmation of the role of socioeconomic explanatory factors such as marital status and wage, relevance of physiological data could be seen from insurance purchase. Moreover, the Probit model results showed the physiological data relevance. There was a possibility for individuals who sought for risk to have higher demand for insurance demand, which could be reflected from their lower task performance. However, they would also be capable of feeling the adaptive risk, which could be seen from how adverse deck was 
INTERNATIONAL JOURNAL OF ACADEMIC RESEARCH IN BUSINESS AND SOCIAL SCIENCES Vol. 8, No. 12, Dec, 2018, E-ISSN: 2222-6990 @ 2018 HRMARS

expected from the responses by skin conductance. The results specifically of the importance of interdisciplinary research were discussed. From that, the relationships are hypothesized as follows:

Hypothesis 5: The association between organization's characteristics and demand for general Takaful is mediated by risk-taking propensity in entrepreneurship

\section{Proposed Models of the Adoption of the Demand for General Takaful}

This study focuses on MSMEs' demand for General Takaful in Malaysia. Following after the focus on the mediator (Risk-taking propensity Actions) by previous studies, a framework is proposed, as displayed in Figure 2 below:

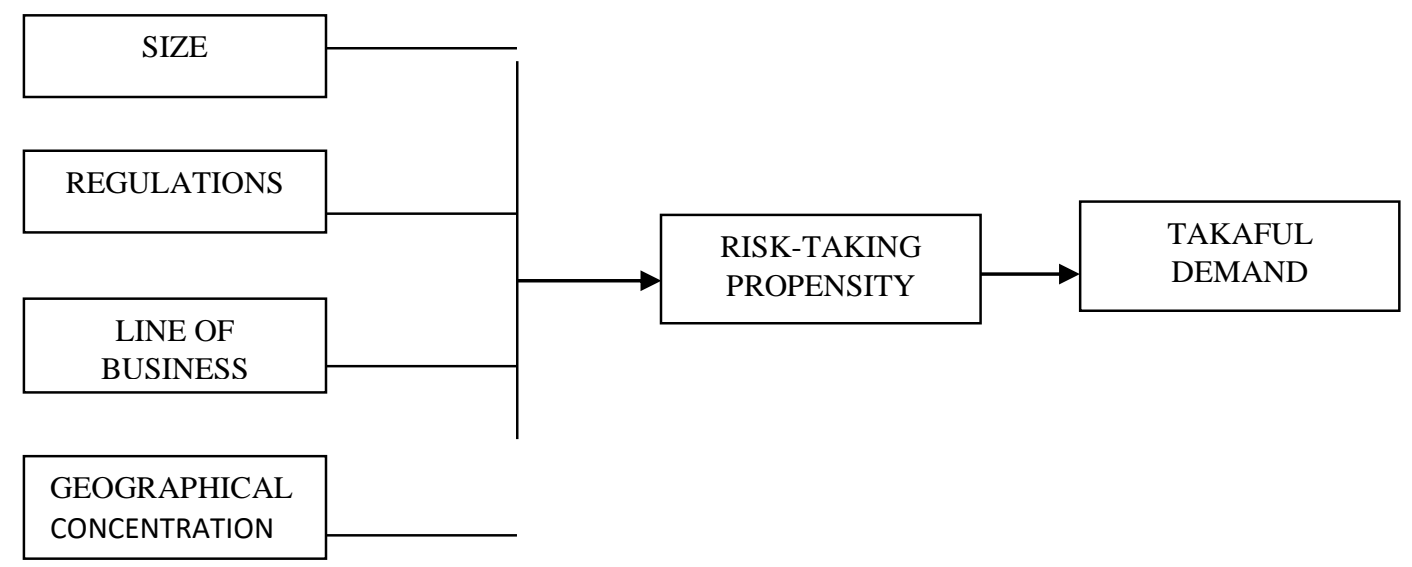

Figure 2: Model for the General Takaful Demand

\section{Conclusions}

In this paper, a review was written on the models for the literature regarding insurance demand at the degree of organization. The CAPM and expected utility theory were the two theories which most of the empirical studies on this matter were based on. Due to the inclusion of the context of risk-taking propensity in the general demand for Takaful demand framework (with exclusion of the general insurance theory), the general demand for Takaful could be described in an easier way. Therefore, this model, compared to the models in other investigations, was considered to be more complete in this research. In fact, Takaful framework has solid theoretical basis. It also receives constant empirical support, and it has the potential of integration in various applications and. Subsequently, an extensive analysis was performed on the general demand for Takaful demand framework. Moreover, empirical studies which only involved the model of general demand for insurance was analyzed, as well as the empirical studies which incorporated this model with general insurance demand and consumer behavior theories. It was concluded that various factors are possibly present within similar context in a particular theoretical model. 
INTERNATIONAL JOURNAL OF ACADEMIC RESEARCH IN BUSINESS AND SOCIAL SCIENCES

Vol. 8, No. 12, Dec, 2018, E-ISSN: 2222-6990 C 2018 HRMARS

\section{References}

Adams, M., Lin, C., \& Zou, H. (2011). Chief Executive Officer Incentives, Monitoring, and Corporate Risk Management: Evidence from Insurance Use. Journal of risk and Insurance, 78(3), 551-582.

Balabanis, G. I., and E. S. Katiskea. 2003. Being an entrepreneurial exporter - does it pay? International Business Review 12:233-52

Burhan, N. A. S., Razak, R. C., Salleh, F., \& Tovar, M. E. L. (2017). The higher intelligence of the 'creative minority'provides the infrastructure for entrepreneurial innovation. Intelligence, 65, 93106.

Burhan, N. A. S., Salleh, F., \& Burhan, N. M. G. (2015). National intelligence and private health expenditure: Do high IQ societies spend more on health insurance? Intelligence, 52, 1-8.

Burnett, J. J. \& Palmer, B. A. (1984). Examining life insurance ownership through demographic and psychographic characteristics. Journal of Risk and Insurance, 51(3), 453-467.

Carland, J.W., III, Carland, J.W., Carland, J.A \& Pearce, J.W. (1995). Risk Taking propensity among entrepreneurs, small business owners and managers. Journal of Business and Entrepreneurship, 7(1): 15-23.

Chen, T.-j., \& Li, S.-h. (2010). Directors' \& officers' insurance, corporate governance and firm performance. International Journal of Disclosure and Governance, 7(3), 244-261.

Cole, C. R., \& McCullough, K. A. (2006). A Reexamination of The Corporate Demand for Reinsurance. Journal of risk and Insurance, 73(1), 169-192.

Eisenhauer, J. G. (2004). Risk aversion and the willingness to pay for insurance: a cautionary discussion of adverse selection. Risk Management and Insurance Review, 7(2), 165-175.

Fang, Y., Kui, C., \& Zhu, M. (2011). Demand for Corporate Insurance in China. Chinese Economy, 44(6), 15-29. doi: 10.2753/1097-1475440602

Hoy, M. \& Robson, A. (1981). Insurance as a Giffen Good. Economics Letters, 8(), 47-51

Hamid, M. A., Osman, J., \& Nordin, B. (2009). Determinants of corporate demand for Islamic Insurance in Malaysia. International Journal of Economics and Management, 3(2), 278-296.

Hoyt, R. E., \& Ho, K. (2000). On the demand for corporate property insurance. Journal of risk and Insurance, 67(1), 91-107.

Ibrahim, MD., Salleh, F., and Awang, Z.,(2015) "The Effects of Financial Factors on Takaful Demand in Malaysia". Journal of Entrepreneurship and Business, 3 (1). pp. 17-29. ISSN 2289-8298

Jacobson, S. \& Petrie, R. (2009). Learning from mistakes: What do inconsistent choices over risk tell us? Journal of Risk and Uncertainty, 38, 143-158

Khan, Muhsin. Surah Al Maidah. Quran in Word, 1.3, 2. Retreived from http://www.geocities.com/mtaufiq.rm/quran.html

Khan, Muhsin. Surah Al Imran. Quran in Word, 1.3, 104. Retreived from http://www.geocities.com/mtaufiq.rm/quran.html

Koiranen, M., Hyrsky, K. \& Tunnanen, M. (1997). Risk-taking propensity of us and Finnish sme's: Findings on similarities and differences, Academy of Entrepreneurship Journal, 2(2), 59-69.

Leko-Simic. M \& Horvat J. (2006). Risk Taking Propensity and Export Performance of Creation Exports. Manging Global Transitions 4(4): 313-326

Mayers, D., \& Smith Jr, C. W. (1990). On the corporate demand for insurance: evidence from the reinsurance market. Journal of Business, 19-40. 
INTERNATIONAL JOURNAL OF ACADEMIC RESEARCH IN BUSINESS AND SOCIAL SCIENCES

Vol. 8, No. 12, Dec, 2018, E-ISSN: 2222-6990 C 2018 HRMARS

Michel-Kerjan, E., Raschky, P., \& Kunreuther, H. (2011). Corporate demand for insurance: An empirical analysis of the US market for catastrophe and non-catastrophe risks: National Bureau of Economic Research.

Nicholson, N., Fenton-O'Creevy, M., Soane, E. and P. Willman, 2002, Risk propensity and personality. COR working paper.

Ottaviani C. and D. Vandone (2011), Decision-making under uncertainty and demand for insurance: an empirical study, Departemental Working Papers, Department of Economics, Business and Statistics at Università degli Studi di Milano, http://econpapers.repec.org/RePEc:mil:wpdepa:2011-05.

Salleh, F., Ibrahim, MD., Awang. Z., Yazid, AS., Wan Daud,WN., Abdul Razak, R., Yaakub, N., Ghazali, PL., Mohamad, M., and Hashim, NH., (2017) "Does Perception Towards Insurable Risks Mediate the Relationship Between Firm's Leverage and General Takaful Demand?"World Applied Sciences Journal 35 (8) pp 1423-1433, ISSN 1818-4952

Schlesinger, H. (1981). The optimal level of deductibility in insurance contracts. Journal of Risk and Insurance, 48(4), 465-481.

Szpiro, G. E. (1986). Measuring risk aversion: an alternative approach. Review of Economics and Statistics, 63, 156-159.

Yamori, N. (1999). An empirical investigation of the Japanese corporate demand for insurance. Journal of risk and Insurance, 66(2), 239-252.

Zou, H., Adams, M. B., \& Buckle, M. J. (2003). Corporate risks and property insurance: Evidence from the People's Republic of China. Journal of risk and Insurance, 70(2), 289-289. 